\section{A HITHERTO UNPUBLISHED LETTER OF ISAAC NEWTON}

$\mathrm{T}$ HE Royal Society recently received, on indefinite loan from its present owner, a hitherto unrecorded autograph letter of Isaac Newton. The letter is a long one, it has an intrinsic interest for the history of science, it is in a remarkably good state of preserva. tion and its authenticity is established with unusual completeness. It was written in 1677 from Cambridge to the Hon. and Rev. Dr. John North, then living in London, but later Master of Trinity College, Cambridge. The present owner of the letter, Mr. Roger North, of Rougham, King's Lynn, Norfolk, who has placed it in the custody of the Royal Society, makes the very probable suggestion that the "new Treatise of Musick", with which the letter deals, was "A Philosophical Essay on Music", by Francis North, Lord Guilford, to whose brother the letter is addressed.

The letter is written on both sides of a sheet of paper measuring about $15 \frac{1}{2}$ in. by 12 in., in a very neat and easily legible hand, which is certainly that of Newton. One half of one side was left blank, so that on folding for postage it could be addressed without envelope. On one of the blank oblongs left by this folding, the letter has been further identified by endorsements written by (1) Roger North, son of the Hon. Roger North of Rougham and nephew of Dr. John North, the recipient ; and (2) Frederick North, great-grandson of (1) and great-grandfather of the present owner, Mr. Roger North of Rougham. The fine state of preservation is explained by the fact that, as Mr. North informs me, the letter had been kept continuously between the leaves of a folio volume in the family library, until he recently had it framed between plates of glass.

The scientific world is indebted to Mr. North's generous thought, which has now made the letter available for study by placing it in the Royal Society's library. The publication of the following text of the document will, meanwhile, make its substance available to the readers of Nature.

\section{H. H. Date.}

\section{Cambridge Apr 21.1677}

$\mathrm{Sr}$

The esteem you express of my judgment I must impute to $y^{x}$ goodness who are willing to make $\mathrm{y}^{\circ}$ best of every thing. Yet since it is yo desire to have my opinion about this new Treatise of Musick, I shall give it you, though perhaps not so largely as you may expect, there being some things which I cannot speak positively to for want of experiments \& skill in Musick.

Pag 5 lin 14 \& pag 6 lin 30, the Author asserts $y^{t}$ sound is producod in $\mathrm{y}^{\circ}$ Torricellian vacuum, \& thence seems to collect $\mathrm{y}^{t} \mathrm{y}^{e}$ medium of sound is not $y^{\circ}$ grosser Air but some subtiler aerial fluid of $a$ middle nature between $y^{\mathfrak{t}}$ Air \& AEther, wch can penetrate glass \& other gross bodies. But it is to be suspected $\mathrm{y}^{t}$ this experim ${ }^{t}$ of $\mathrm{y}^{*}$ Torricellian Vacuu holds only when $y^{\circ}$ glas is not well emptied of Air. For $M$ r Boyle (Expt 27) repeating it $w^{\text {th }}$ a watch hung in his Receiver, found that as $\mathrm{y}^{\circ}$ receiver was more \& more emptied, y* noise made by y Ballance wheel grew fainter \& fainter till at last it was not heard at all though $\mathrm{y}^{\bullet}$ handle \& wheels of $\mathrm{y}^{\bullet}$ watch were still seen to continue their motion as freely as at first. Yet $y^{\circ}$ louder sound of a Bell continued audible when $\mathrm{y}^{\bullet}$ air was drawn out, though perhaps it would not have done so could $y \cdot$ Receiver have been fully exhausted of Air, \& $y \cdot$ Bell have been susteined in $y^{*}$ Receiver by something $w^{\circ h}$ might not touch $\mathrm{y}^{\bullet}$ glas. To $\mathrm{y}^{\bullet}$ best of my remembrance I have also some where read of an Alarm Watch whose Alarm being made to go, $\mathrm{y}^{\bullet}$ sound of $y^{*}$ Bell grew faint by drawing out $y^{\bullet}$ air.

Pag 5 lin 18 The Author asserts $y^{\prime}$ a sound seems to come in streight lines to $\mathrm{y}^{\circ}$ ear though an obstacle be situated between $\mathrm{y}^{\bullet}$ ear $\& \mathrm{y}^{\bullet}$ sounding body so $\mathrm{y}^{\boldsymbol{t}}$ it cannot come in streight lines. But this I doubt of if, he mean $y^{\prime}$ it seems to come in streight lines from $\mathrm{y}^{*}$ sounding body. If indeed $\mathrm{y}^{\circ}$ interposed obstacle be not too gross \& compact, suppose a glass window or thin wall of wood or mortar, y air may by shaking it propagate $\mathrm{y}^{\circ}$ sound through it, \& then $y^{\circ}$ sound will be heard in a streight line from $y^{\circ}$ sounding body: but if $\mathrm{y}^{\bullet}$ obstacle be massy, suppose a very steep \& high hill or a sollid high wall of brick or stone, I am apt to think $\mathrm{y}^{\bullet}$ sound will seem to come from $y^{\bullet}$ top of $y^{\bullet}$ Hill or Wall rather then in a direct line from $y^{\circ}$ sounding body behind it. And some such diverting of sounds I have observed occasionally, in walking on a street close by a single house whilst bells were ringing on $\mathrm{y}^{\bullet}$ other side. The house to $\mathrm{y}^{\bullet}$ best of $\mathrm{my}$ remembrance had no windows on that side next me \& $y^{\circ}$ sound of $y^{\bullet}$ bells seemed to come from $y^{2}$ end of $y^{0}$ house $\mathrm{w}^{\circ} \mathrm{b}$ I was nearest to, though $\mathrm{y}^{\circ}$ bells were directly behind it so in a Room of stone walls $w^{\text {: }}$ but one window, the sound will seem to come from $y^{\bullet}$ window though $\mathrm{y}^{\bullet}$ sounding body without lye not that way.

Pag 8 lin 14 The Author affirms $y^{t}$ where $y^{\bullet}$ vibrations of two sounding strings are equal, they will work one another to a coincidence or synchronism, \& on this position grounds all his discours of concords \& discords, affirming $\mathrm{y}^{\mathrm{t}}$ unisons alway strike $\mathrm{y}^{\bullet}$ ear together, Octaves at every other puls of $y^{\bullet}$ Treble, fifts at every 3 * pulse \&c. But it seems otherwise to me for though $\mathrm{y}^{\bullet}$ pulses of $\mathrm{y}^{\bullet}$ strings should reduce one another to a synchronism, yet those of one string will strike $y^{*}$ ear sooner or later then those of $\mathrm{y}^{\bullet}$ other, accordingly as $\mathrm{y}^{\bullet}$ ear is more or less near to one string then to ye other.

Since sounds are not propagated in a moment, $\mathrm{y}^{\circ}$ pulses must not be supposed to extend each of them at once from $\mathrm{y}^{\bullet}$ sounding body to $\mathrm{y}^{\bullet}$ ear in such manner $y^{*}$ all. $y^{*}$ air in that interval be moved together first forward \& then backward, \& so forward \& backward again so long as $y^{*}$ sound lasts : but $y^{\bullet}$ pulses are rather to be conceived like so many spherical concentrick waves whose center is $\mathrm{y}^{\circ}$ sounding body \& $\mathrm{w}^{\circ \mathrm{b}}$ arising continually from $\mathrm{y}^{\mathrm{t}}$ center dilate \& flow on from thence with that swiftness we find sound propagated till they arrive at $y$ ear ; new pulses from $y^{\bullet}$ center continually succeeding them after $\mathrm{y}$ ' manner of undulations made by throwing a stone into water. Let therefore $A$ \& $B$ represent two sounding bodies of like tones, c,d,e,f, \&c $y^{*}$ pulses continually propagated from $\mathbf{A} ; \& \&, 1, m, n$, \&c $\mathrm{y}^{\bullet}$ pulses propagated from $\mathrm{B}$. And if $\mathrm{y}^{\bullet}$ ear be placed at $x$, or $y$, or $z$, or any place where $y^{\bullet}$ pulses at any time intersect, they will strike $y^{\bullet}$ ear at $y^{\bullet}$ same time, but if it be placed between $x, \& y$ suppose at $v, y^{*}$ puls $x n w^{\circ n}$ comes from $y^{\bullet}$ Body $B$ will strike it in $\mathrm{y}^{\bullet}$ intervall of $\mathrm{y}^{\bullet}$ pulses $\mathrm{xf} \& \mathrm{yg} \mathrm{w}^{\circ \mathrm{b}}$ come from $y^{\circ}$ body A. And the like will happen if 


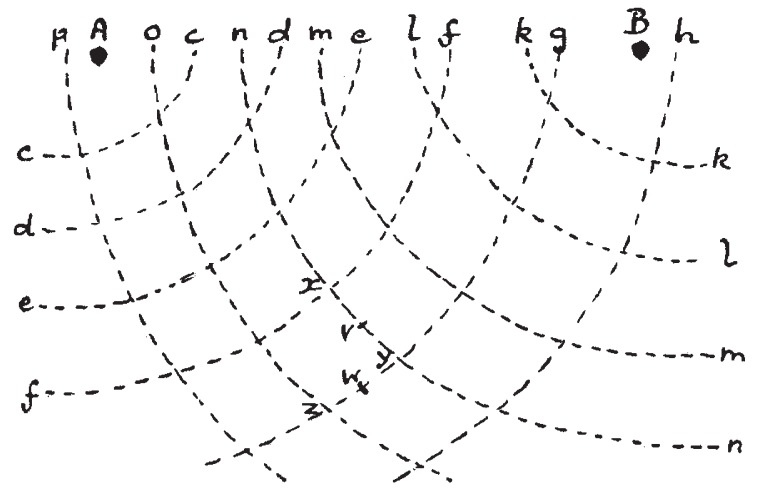

$y^{\circ}$ ear be placed between $y \& z$ as at $w$, or in any pulse of one body \& between two pulses of $y^{\bullet}$ other. So that $y^{\bullet}$ ears of two men or $y^{\bullet}$ two ears of $y^{\bullet}$ same man according to their position from $y^{\circ}$ sounding bodies may be struck the one at once $y^{\circ}$ other successively by $\mathrm{y}^{*}$ pulses, \& yet in all positions of $\mathrm{y}^{\bullet}$ ear $\mathrm{y}^{\bullet}$ sounds \& their harmony are heard $\mathrm{y}^{\circ}$ same. The like of bodies tuned to a fift or any other Concord. Seing therefore y pulses of two sounds may at $y^{\circ}$ same time strike one ear both together \& another ear alternately \& yet do exhibit $\mathrm{y}^{\bullet}$ same concord to all ears, it follows $1^{\text {at }}$ that concords arise not from $y^{\circ}$ coincidence of pulses at $y^{\circ}$ ear nor have any dependance on such coincidences, \& 2 a1s that unisons are rather a harmony of two like tones then a single tone made more loud and full by $y^{\circ}$ addition as $\mathrm{y}^{\circ}$ author would have it, p.8.1.20.

The explication of $y^{*}$ sound of whistles pag 12 is very ingenious, but I fear not altogether substantial. Yet for want of apposite experiments I can neither sufficiently confute it nor confirm any new Hypothesis.

The discours also about breaking of Tones into higher notes seems very ingenious \& judicious, but I want experience to discern whether altogether solid, \& much more do I want experience \& skill to enable me sufficiently to judge of what follows about Tunes, $y^{*}$ scale of Music, \& consort; this requiring a combination of musical \& mathematical skill, \& therefore I shal content my self $w^{\text {th }}$ having thus far animadverted upon $\mathrm{y}^{\circ}$ Author.

I am much obliged to you for giving me notice of the objection made against my notion about colours. But $y^{\bullet}$ experiment succeeds otherwise then tis reported. If you place your eye where $y^{\bullet}$ blew light falls on $\mathrm{y}^{\mathrm{e}}$ wall so $\mathrm{y}^{\mathrm{t}}$ a by-stander see your eye of a blew colour you will at $y^{\circ} \operatorname{same}$ time see $y^{*}$ Prism of a blew colour; and so if you place you eye in $y^{\circ}$ red light you will see $y^{\circ}$ Prism red. What colour a By-stander sees fall on yo ${ }^{2}$ eye you will see at $y^{\circ}$ Prism : as I oan affirm by iterated experience.

The last week I called at yo Lodgings \& hope ere long to have an opportunity to wait on you again. In $\mathrm{y}^{\mathrm{a}}$ meane time $I$ rest $\mathrm{w}^{\mathrm{th}}$ my thanks to you for yor kind acceptance of my former Letters

$Y_{0} \times$ humble Servant \& honourer

Is. Newton

For the Ra \& Hon b1.

Dr North, to be left

at $\mathrm{Mr}$ Pawley's at

the Bible in

Chancery Lane

London

\section{ENZYME ACTIVITY AS A FACTOR IN INSECT PHYSIOLOGY AND TOXICOLOGY}

\author{
By DR. H. HURST \\ Department of Colloid Science, Cambridge
}

$\mathrm{F}_{\mathrm{p}}^{\mathrm{o}}$ OR many years the search for new insecticides has proceeded on the working hypothesis that toxicity is related to highly specific molecular configurations in the insecticide molecules. An excellent example of the analytical approach used by the chemist has been provided recently by Läuger, Martin, and Müller, who have made an exhaustive and critical examination of the constitution and toxic action of natural insecticides, such as pyrethrins and rotenone, and in particular, the new synthetic insecticide D.D.T. $(\alpha, \alpha$-bis-(4-chlorphenyl)- $\beta, \beta, \beta$-trichloroethane $)^{1}$. But before any evaluation of insecticidal activity may be made in terms of specific group concepts, it is necessary to take into account some less specific dynamic factors in activity. In this connexion, the carrier medium in which an insecticide is dissolved may alter the permeability of the insect cuticle and so modify access of insecticide to the internal tissues ${ }^{2}$.

The importance of this rate factor in access of insecticide becomes apparent if we make the valid assumption that insecticidal activity is associated with some disturbance in the chain of consecutive vital processes which regulate the dynamic balance in internal tissue metabolism. If gross biological responses, such as paralysis or death, can be identified more specifically with changes in enzyme activity, a step forward will have been taken towards the elucidation of the more interesting anomalous sys. tems in insect toxicology where there is no apparent coincidence between molecular structure and insecticidal activity.

These concepts will be illustrated in the present article, where an attempt is made to define the biophysical factors which influence the uptake of insecticide by the insect cuticle and internal tissue receptors. Some new factors in insecticidal activity will be described, depending on the discovery that phenoloxidase activity in the cuticle and sensitive tissue receptors* may be greatly modified by the selective environmental influence of the structural components associated with the enzymes in vivo, Narcosis, or knock-down action, may involve the indirect blocking of enzyme activity by the adsorption of insecticide on the protective lipo-protein tissue components. Lethality usually involves an irreversible inorease in phenoloxidase activity owing to the displacement of proteotive lipoid from the tissue receptor complex. This stage is accompanied by the accumulation of toxic quinonoid metabolites in the blood and tissues, and is oharacteristic of the lethal action of insecticides and simpler fat-soluble dyugs. Relative susceptibility of insects to contact insecticides depends partly on cuticle permeability, but more fundamentally on the stability of the internal tissue receptors which regulate the internal balance in oxidative metabolism.

Apart from differences in molecular structure, insecticides as a class are fat-soluble. The access of contact insecticides involves the uptake and storage of insecticide by the outer lipophilic epicuticle layer

* The term 'receptors' is frequently used in pharmacology to indicate the sites of action in biological svstems with which drugs are supposed to combine or exert specifle actions. 